\title{
KORELASI KADAR CD4 DENGAN KADAR HEMOGLOBIN SEBELUM TERAPI ARV PADA PENDERITA HIV/AIDS DI RSUD DR. H. ABDUL MOELOEK PROVINSI LAMPUNG TAHUN 2017
}

\author{
Neno Fitriyani Hasbie ${ }^{1}$, Ade Utia Detty ${ }^{2}$, Syuhada $^{3}$, Meta Mediana ${ }^{4}$ \\ ${ }^{1}$ Departemen Ilmu Kedokteran Komunitas, Fakultas Kedokteran, Universitas \\ Malahayati \\ ${ }^{2}$ Departemen Imunologi, Fakultas Kedokteran, Universitas Malahayati \\ ${ }^{3}$ Bagian Patologi Klinik, Rumah Sakit Umum Abdul Muluk, Bandar Lampung \\ ${ }^{4}$ Program Studi Kedokteran, Fakultas Kedokteran, Universitas Malahayati
}

\begin{abstract}
Correlation of CD4 Levels with Hemoglobin Levels Before ARV Therapy in HIV / AIDS Patients in RSUD Dr. H. Abdul Moeloek Lampung Province in 2017. In HIV patients, there are many clinical abnormalities. Hematologic abnormalities are among the most common manifestations of advanced human immunodeficiency virus (HIV) infection and acquired immunodeficiency syndrome (AIDS). Low blood cells count, are the most common of these disorders. The frequency and severity of these hematological manifestations increased with the decline in CD4 counts and hemoglobin counts. This study aimed to determine the correlation of CD4 levels and Hemoglobin levels before ARV therapy in people with HIV / AIDS in the RSUD DR. H. Abdul Moeloek Lampung Province in 2017. This study was analitic quantitative research with cross sectional approach. This study was conducted from medical record from Januari to December 2017 in RSUD DR. H. Abdul Moeloek Lampung Province. A total of 102 patients were selected using purposive sampling. Statistical analysis of the data was used spearman test. Was done using SPSS version 18. The results showed that the average level of hemoglobin level was $12,421 \pm 12,7 \mathrm{gr} / \mathrm{dl}$ and the average CD4 level was $151.36 \pm 89.0$ cells / mm3. There was a significance correlates with CD4 levels and hemoglobin levels before ARV therapy, the value of $p=0.00$ ( $p$ value $<0,05$ ). The correlation coefficient was 0,458 showed positive correlation with average. $\mathrm{H}_{1}$ is received with a positive correlation with weak strengths. statistically significant between $\mathrm{Hb}$ levels and CD4 levels in HIV / AIDS patients who have not received ARV therapy so that they can be used as a marker for increasing CD4 levels.
\end{abstract}

Keywords: HIV, Hemoglobin, CD4, ARV.

Abstrak: Korelasi Kadar CD4 dengan Kadar Hemoglobin Sebelum Terapi ARV Pada Penderita HIV/AIDS Di RSUD Dr. H. Abdul Moeloek Provinsi Lampung Tahun 2017. Pada pasien HIV, ada banyak kelainan klinis yang didapat. Abnormalitas hematologi adalah salah satu manifestasi paling umum dari infeksi human immunodeficiency virus (HIV) tingkat lanjut dan acquired immunodeficiency syndrome (AIDS).Jumlah sel darah merah rendah, adalah yang paling umum dari gangguan ini. Frekuensi dan keparahan manifestasi hematologi dapat mempengaruhi jumlah CD4 dan kadar hemoglobin. Tujuan penelitian ini adalah untuk mengetahui korelasi kadar CD4 dan kadar Hemoglobin sebelum terapi ARV pada penderita HIV/AIDS di RSUD DR. H. Abdul Moeloek Provinsi Lampung Tahun 2017. Penelitian ini merupakan sebuah studi cross sectional dilakukan dari rekam medis dari Januari hingga Desember 2017 di RSUD DR. H. Abdul Moeloek Provinsi Lampung. Sebanyak 102 pasien dipilih menggunakan purposive sampling. Analisis menggunakan analisa univariat dan bivariat dengan uji spearman. Hasil penelitian menunjukkan bahwa tingkat rata-rata tingkat hemoglobin adalah $12,421 \pm 12,7 \mathrm{gr}$ / dl dan tingkat CD4 rata-rata adalah 151,36 $\pm 89,0$ sel / mm3. Ada hubungan yang bermakna dengan kadar CD4 dan kadar hemoglobin sebelum terapi ARV, nilai 
$p=0,00$ (nilai-p <0,05). Koefisien korelasi sebesar 0,458 menunjukkan korelasi positif dengan kekuatan sedang. $\mathrm{H}_{1}$ diterima dengan korelasi positif lemah. Secara statistik signifikan antara kadar Hemoglobin dengan kadar CD4 pada penderita HIV/AIDS yang belum mendapatkan terapi ARV sehingga dapat digunakan sebagai penanda penurunan kadar CD4.

Kata Kunci: HIV, Hemoglobin, CD4, ARV.

\section{PENDAHULUAN}

AIDS

Immunodeficiency Syndrome) dapat diartikan sebagai kumpulan gejala atau penyakit yang disebabkan oleh menurunnya kekebalan tubuh akibat infeksi oleh virus HIV (Human Immunodeficiency Virus). HIV merupakan virus yang termasuk famili retroviridae (Djoerban dan Djauzi, 2014).

Berdasarkan data terakhir UNAIDS (Joint United Nations Programme on HIV and AIDS)pada tahun 2016 terdapat 36,7 juta orang di seluruh dunia hidup dengan HIV. Terdapat 1,8 juta orang kasus HIV baru, dan juga sekitar $53 \%$ dari semua orang yang hidup dengan HIV telah memiliki akses pengobatan pada tahun 2016.

$\mathrm{Di}$ Indonesia, HIV AIDS pertama kali ditemukan di Provinsi Bali pada tahun 1987. Hingga saat ini HIV AIDS sudah menyebar di 407 dari 507 kabupaten/kota (80\%) di seluruh provinsi di Indonesia (Ditjen PP dan $P L, 2016)$. Jumlah orang dengan HIV/AIDS di Indonesia pada bulan Januari sampai Maret 2017 adalah sebanyak 10.376 orang dengan jumlah kematian AIDS sebanyak 61 orang (Kemenkes, 2017).

Kasus HIV/AIDS dilaporkan pertama kali di Provinsi Lampung pada tahun 2002 dari salah satu Kabupaten di Provinsi Lampung. Jumlah kasus HIV/AIDS yang dilaporkan dari seluruh Kabupaten/Kota tahun 2002 sampai dengan 2015 terus meningkat.Distribusi kasus HIV/AIDS per- Kabupaten Kota Se-Provinsi Lampung tahun 2015 terlihat bahwa kasus terbanyak ada di kota Bandar Lampung, dengan angka kejadian sebanyak 314 HIV dan 57 AIDS
(Dinas Kesehatan Provinsi Lampung, 2015). Menurut data Kementerian Kesehatan per 17 Desember 2017 jumlah kasus baru HIV Provinsi Lampung tahun 2017 sebanyak 583 orang (Kemenkes RI, 2018).

Pada pasien HIV, ada banyak kelainan klinis yang didapat. Salah satunya adalah gangguan hematologi.

Jumlah sel darah merah rendah, adalah yang paling umum dari gangguan ini. Frekuensi dan keparahan manifestasi hematologi dapat mempengaruhi peningkatan dan penurunan jumlah CD4 dan kadar hemoglobin, anemia menjadi kelainan hematologi yang paling umum pada pasien HIV dan dikaitkan dengan perkembangan penyakit dan penurunan kelangsungan hidup. Namun, prevalensi anemia pada pasien HIV bervariasi, mulai dari 1,3 hingga $95 \%$. Beberapa faktor termasuk stadium HIV, usia, jenis kelamin dan definisi anemia yang digunakan dikatakan variasi prevalensi HIV (Woldeamanuel,2018).

Penyebab umum lain anemia pada AIDS adalah anemia penyakit kronis, penekanan sumsum tulang oleh Antiretroviral (ARV), dan anemia hemolitik yang diinduksi oleh obat oksidan. Sitokin seperti Interleukin 1, Tumor Necrosis Factor (TNF) dan interferon berperan dalam merusak respon erythropoietin dengan mengurangi konsentrasi sumsum tulang belakang dan koloni erythroid (Woldeamanuel,2018). Proses apoptosis dikatakan menjadi hal utama dari penurunan $\mathrm{Hb}$ dan CD4. $\mathrm{Hb}$ dikaitkan dengan apoptosis sel progenitor eritroid sedangkan CD4 dihubungkan dengan proses apoptosis limfosit $T$ (NW Cummins,2010). Penurunan $\mathrm{Hb}$ secara patogenesis 
terjadi melalui 2 mekanisme yaitu: activation induced cells death dan peningkatan produksi interferon- $\mathrm{Y}$. activation induced cells death merupakan proses apoptosis sel CD4 teraktivasi oleh antigen melalui ikatan antigen precenting cell dengan gp 120 pada reseptor CD4. Sedangkan peningkatan interferon- $y$ yang terjadi karena disregulasi sitokin akibat infeksi virus HIV akan menekan proses eritropoesis dan meningkatkan proses apoptosis sel progenitor eritroid (Wipasa, 2014).

Menurut penelitian sebelumnya yang di lakukan di RSUP Sanglah, Kota Denpasar, Bali korelasi antara kadar $\mathrm{Hb}$ dan jumlah limfosit T CD4+ tampak hubungan linear dengan uji korelasi Spearman didapatkan korelasi positif kuat yang signifikan antara kadar $\mathrm{Hb}$ dan jumlah limfosit $\mathrm{T}$ CD4+ $(r=0,698 ; p<0,001)$ (Dwiadnyana, 2017). Berdasarkan kasus HIV/AIDS di Provinsi Lampung terbanyak terjadi di kota Bandar Lampung serta belum adanya penelitian mengenai korelasi kadar CD4 dan kadar Hemoglobin sebelum terapi ARV pada penderita HIV/AIDS di RSUD DR. H. Abdul Moeloek Provinsi Lampung Tahun 2017, maka peneliti tertarik untuk melakukan penelitian tersebut.

\section{METODE}

Penelitian ini merupakan jenis penelitian yang bersifat analitik observasional dengan pendekatan cross sectional. Penelitian ini dilakukan di RSUD Dr. H. Abdul Moeloek Provinsi Lampung Provinsi Lampung, pada bulan Oktober 2018 Februari 2019. Jumlah sampel pada penelitian ini adalah 102 sampel dengan teknik sampling yaitu purposive sampling, dengan kriteria inklusi:

1. Penderita HIV yang memeriksan kadar Hb sebelum terapi ARV

2. Penderita yang memeriksakan CD4 sebelum terapi ARV

3. Penderita HIV laki-laki dan perempuan yang berusia $\geq 18$ $<60$ tahun

4. Penderita HIV yang memiliki rekam medis lengkap

kriteria eksklusinya sebagai berikut:

1. Perdarahan akut atau kronis

2. Penderita dengan infeksi dan inflamasi kronis

3. Anemia hemolitik autoimun Data pada penelitian ini adalah data primer. Data penelitian ini dianalisa secara univariat dan bivariat dengan uji korelasi.

\section{HASIL}

Adapun karakteristik berdasarkan jenis kelamin, umur, pendidikan, pekerjaan, stadium klinik, transmisi dam kadar CD4. Dapat dilihat pada tabel berikut ini:

Tabel 1. Karakteristik Subjek Penelitian Berdasarkan Jenis Kelamin, Umur, Pendidikan, Pekerjaan, Stadium Klinis, Transmisi dan Kadar CD 4

\begin{tabular}{lcc}
\hline & Responden & Persentase (\%) \\
\hline Jenis Kelamin & & \\
Laki-laki & 86 & 84,3 \\
Perempuan & 16 & 15,7 \\
\hline Umur & & \\
\hline $18-39$ tahun & 79 & $77,5 \%$ \\
$40-59$ tahun & 21 & $20,6 \%$ \\
$>50$ tahun & 2 & $2,0 \%$ \\
\hline Pendidikan & & \\
Tidak Sekolah & 2 & $2,0 \%$ \\
SD & 4 & $3,9 \%$ \\
SMP & 13 & $12,7 \%$ \\
SMA & 50 & $49,0 \%$ \\
Perguruan Tinggi & 29 & $28,4 \%$
\end{tabular}




\begin{tabular}{lcc} 
Tidak Diketahui & 4 & $3,9 \%$ \\
\hline Pekerjaan & 30 & $61,8 \%$ \\
Bekerja & 32 & $34,3 \%$ \\
Tidak Bekerja & 4 & $3,9 \%$ \\
Tidak Diketahui & 17 & $16,7 \%$ \\
\hline Stadium Klinik & 24 & $23,5 \%$ \\
1 & 43 & $42,2 \%$ \\
2 & 7 & $6,9 \%$ \\
3 & 11 & $10,8 \%$ \\
4 & & \\
Tidak Diketahui & & \\
\hline Transmisi & 32 & $31,4 \%$ \\
Heteroseksual (Lebih & 24 & $23,5 \%$ \\
dari 1 pasangan) & 2 & $2,0 \%$ \\
Homoseksual & 1 & $1,0 \%$ \\
Biseksual & 3 & $2,9 \%$ \\
Transfusi Darah & 12 & $11,8 \%$ \\
Napza Suntik & & \\
Tidak Diketahui & 32 & $31,4 \%$ \\
\hline CD4 (sel/mm ( $^{2}$ ) & 37 & $36,3 \%$ \\
$<50$ & 23 & $22,5 \%$ \\
50 - 199 & 10 & $9,8 \%$ \\
200 - 394 & & \\
$>$ 350 & & \\
\hline
\end{tabular}

Berdasarkan Tabel 1 jenis kelamin terbanyak yaitu laki-laki sebanyak 86 responden $(84,3 \%)$. Umur penderita HIV terbanyak pada usia 18 - 39 tahun sebanyak79 responden $(77,5 \%)$. Jumlah pendidikan tebanyak yaituSMA sebanyak50 responden $(49,0 \%)$. Pekerjaan penderita HIV tebanyak yaitu wiraswasta sebesar 63 responden (35,2\%).Stadium klinis penderita HIV terbanyak yaitu stadium 3 sebanyak 43 responden $(42,2 \%)$. Transmisi tertinggi melalui heteroseksual sebesar 32 responden (31,4\%). Jumlah CD4 HIV terbanyaj yaitu $50-199$ sebanyak 37 responden $(36,3 \%)$.

Tabel 2. Distribusi Frekuensi kadar CD4 dan Kadar Hemoglobin sebelum terapi ARV pada Pasien HIV/AIDS di RSUD DR. H. Abdul Moeloek Provinsi Lampung Tahun 2017

\begin{tabular}{lccc}
\hline \multicolumn{1}{c}{ Parameter } & $\begin{array}{c}\text { Rerata } \pm \\
\text { SB/Median }\end{array}$ & Terendah & Tertinggi \\
\hline Kadar CD4 & $\begin{array}{l}151,36 \\
(89,0)\end{array}$ & 0 & 608 \\
$\begin{array}{l}\left(\mathrm{sel} / \mathrm{mm}^{3}\right) \\
\text { Kadar Hemoglobin }\end{array}$ & $\begin{array}{l}12,421 \\
(12,7)\end{array}$ & 6,4 & 18,5 \\
$(\mathrm{gr} / \mathrm{dl})$ & & & \\
\hline
\end{tabular}

Tabel 2 memperlihatkan distribusi frekuensi kadar CD4 dan kadar Hemoglobin sebelum terapi ARV pada penderita HIV/AIDS di RSUD DR. H. Abdul Moeloek Provinsi Lampung Tahun 2017. Didapatkan rerata jumlah CD4 yaitu $151,36 \mathrm{sel} / \mathrm{mm}^{3}$ dengan nilai tengah $89 \mathrm{sel} / \mathrm{mm}^{3}$, nilai minimum $0 \mathrm{sel} / \mathrm{mm}^{3}$, dan nilai maksimum yaitu $608 \mathrm{sel} / \mathrm{mm}^{3}$. Sedangkan untuk rerata kadar Hemoglobin yaitu $12,421 \mathrm{gr} / \mathrm{dl}$ dengan nilai tengah $12,7 \mathrm{gr} / \mathrm{dl}$, nilai minumum $6,4 \mathrm{gr} / \mathrm{dl}$, dan nilai maksimum 18,5 $\mathrm{gr} / \mathrm{dl}$. 
Tabel 3. Hasil test uji normalitas, Korelasi Kadar CD4 dengan Kadar .

\begin{tabular}{ccccccc}
\hline & \multicolumn{3}{c}{ Kolmogorov-Smirnov } & \multicolumn{3}{c}{ Shapiro-Wilk } \\
\cline { 2 - 7 } & Statistic & df & Sig. & Statistic & Df & Sig. \\
\hline Kadar CD4 &, 201 & 102 &, 000 &, 852 & 102 &, 000 \\
\hline Kadar Hb &, 068 & 102 &, 200 &, 984 & 102 &, 257 \\
\hline
\end{tabular}

Berdasarkan tabel 3hasil uji normalitas dengan sampel $>30$ sampel menggunakan kolom Kolmogorov-Smirnov, didapatkan nilai kadar CD4 adalah 0,000 lebih kecil dari 0,05 data tidak terdistribusi normal. Sedangkan, nilai kadar Hemoglobin adalah 0,200 lebih dari 0,05 data terdistribusi normal. Oleh karena itu dilakukan uji korelasi Spearman.

Tabel 4. Hasil analisis uji Korelasi Kadar CD4 dan Kadar Hemoglobin sebelum terapi ARV pada Pasien HIV/AIDS di RSUD DR. H. Abdul Moeloek Provinsi Lampung Tahun 2017

\begin{tabular}{cc}
\hline & Kadar Hemoglobin \\
\hline Kadar CD4 & $P=0,00$ \\
& $\mathrm{r}=0,458$ \\
$\mathrm{n}=102$
\end{tabular}

Uji korelasi spearman

Berdasarkan tabel 4 hasil analisis uji spearman dengan tingkat kesalahan $5 \%$ didapatkan nilai $p=0,00$ dimana nilai $p<0,05$ menunjukan bahwa $\mathrm{H}_{1}$ diterima, artinya bahwa korelasi kadar CD4 dan kadar hemoglobin bermakna. Nilai koefisien korelasi sebesar 0,458 menunjukan korelasi positif dengan kekuatan korelasi sedang.

\section{PEMBAHASAN}

Pada penelitian ini didapatkan nilai $p=0,00$ menunjukan bahwa $\mathrm{H}_{1}$ diterima, artinya bahwa korelasi kadar CD4 dan kadar hemoglobin bermakna. Nilai koefisien korelasi sebesar 0,458 menunjukan korelasi positif dengan kekuatan korelasi sedang.

Gangguan hematologis adalah salah satu bentuk kelainan klinis yang didapat pada pasien HIV, salah satunya adalah gangguan hematologi. Jumlah sel darah merah rendah, adalah yang paling umum dari gangguan ini. Frekuensi dan keparahan manifestasi hematologi dapat mempengaruhi peningkatan dan penurunanya jumlah CD4 dengan anemia menjadi kelainan hematologi yang paling umum pada pasien HIV dan dikaitkan dengan perkembangan penyakit dan penurunan kelangsungan hidup (Woldeamanuel,2018).

Proses apoptosis dikatakan menjadi hal utama dari penurunan $\mathrm{Hb}$ dan CD4. $\mathrm{Hb}$ dikaitkan dengan apoptosis sel progenitor eritroid sedangkan CD4 dihubungkan dengan proses apoptosis limfosit $T$ (Cummins,2010). Penurunan $\mathrm{Hb}$ secara patogenesis terjadi melalui 2 mekanisme yaitu: activation induced cells death dan peningkatan produksi interferon- $\gamma$. activation induced cells death merupakan proses apoptosis sel CD4 teraktivasi oleh antigen melalui ikatan antigen precenting cell dengan gp 120 pada reseptor CD4. Sedangkan peningkatan interferon- $y$ yang terjadi karena disregulasi sitokin akibat infeksi virus HIV akan menekan proses eritropoesis dan meningkatkan proses apoptosis sel progenitor eritroid (Wipasa, 2014).

Hal lain dari penurunan hemoglobin adalah terjadinya anemia, terdapat tiga mekanisme terjadinya anemia pada infeksi HIV: penurunan produksi sel darah merah, peningkatan destruksi sel darah 
merah, dan produksi sel darah merah yang inefektif. Penurunan produksi eritrosit kemungkinan disebabkan oleh infeksi HIV itu sendiri, penurunan produksi eritropeitin endogen, tidak adanya respon terhadap eritropoeitin, atau hypogonadisme. Peningkatan destruksi eritrosit (hemolisis) atau destruksi imatur dari eritrosit di lien sering terjadi pada infeksi HIV. Anemia Hemolitik dapat disebabkan oleh auto antibodi eritrosit, hemophagocytic syndrome, Disseminated Intravascular Coagulation (DIC), Thrombotic Thrombocytopenic Purpura (TTP), atau defisiensi glucose-6-phosphate dehydrogenase

(G6PD)

(Volberding,2004).

Hemolisis juga mungkin berkembang dari obat-obatan yang dikonsumsi. Produksi eritrosit yang inefektif merupakan mekanisme lain dari anemia. Infektivitas produksi eritrosit dapat disebabkan oleh defisiensi nutrisi yang menjadi bahan baku pembentuk eritrosit, sehingga anemia akibat hal ini disebut anemia nutrisional paling sering adalah defisiensi zat besi, asam folat dan Viamin B12. Pada pasien dengan infeksi HIV, defisiensi asam folat secara umum disebabkan oleh baik defisiensi dalam diet maupun oleh keadaan patologis dari jejunum. Vitamin B12 kemungkinan diakibatkan oleh malabsorpsi pada ileum atau dari kerusakan lambung yang disebabkan infeksi oportunistik pada mukosa lambung (Volberding,2004).

Penilaian klinis dan tes laboratorium berperan penting untuk melihat kondisi ODHA sebelum inisiasi ART dan berguna untuk memonitor respons pengobatan dan kemungkinan toksisitas obat ARV diantaranya pemantauan kadar CD4 dan $\mathrm{Hb}$. Pemantauan klinis dalam pengawasan dokter dilakukan rutin minimal sebulan sekali dalam 6 bulan pertama setelah inisiasi ART. Pemantauan oleh dokter selanjutnya dapat dilakukan minimal 3 bulan sekali atau lebih sering, sesuai dengan kondisi dan kepatuhan pengobatan.
ART (Antiretroviral Therapy) atau terapi ARV. Konseling terapi yang memadai sangat penting untuk terapi seumur hidup dan keberhasilan terapi jangka panjang. Isi dari konseling terapi ini termasuk: kepatuhan minum obat, potensi/kemungkinan risiko efek samping atau efek yang tidak diharapkan atau terjadinya sindrom pulih imun (Immune Reconstitution Inflammatory Syndrome/IRIS) setelah memulai terapi ARV, terutama pada ODHA dengan stadium klinis lanjut atau jumlah jumlah CD4 $<100$ $\mathrm{sel} / \mathrm{mm} 3$, dan komplikasi yang berhubungan dengan terapi ARV jangka panjang.

Orang dengan HIV harus mendapatkan informasi dan konseling yang benar dan cukup tentang terapi antiretroviral sebelum memulainya. Hal ini sangat penting dalam mempertahankan kepatuhan minum ARV karena harus diminum selama hidupnya. ODHA diminta berkomitmen untuk menjalani pengobatan ARV secara teratur untuk jangka panjang. Konseling meliputi cara dan ketepatan minum obat, efek samping yang mungkin terjadi, interaksi dengan obat lain, monitoring keadaan klinis dan pemeriksaan laboratorium secara berkala termasuk pemeriksaan CD4 (Permenkes,2014).

Hal ini penting untuk memeriksakan kadar $\mathrm{Hb}$ dan kadar CD4 karena salah satu dari obat ARV yang memiliki efek samping dapat menurunkan hemoglobin, salah satunya adalah obat zidovudin. Dalam guideline terapi ARV oleh WHO juga telah dikatakan bahwa zidovudin merupakan NRTI yang memilik toksisitas supresi sumsum tulang. Penelitian terdahulu telah melaporkan genotoksisitas analog nukleosida yang membawa kepada mutasi, delesi serta kerusakan DNA yang mengakibatkan kerusakan sel tinggi terjadi pada sumsum tulang dan sel darah perifer. Toksisitas ini berkaitan dengan dosis zidovudin. (Fransiska, 2015). Sehingga pengukuran secara teratur dapat membantu menentukan pasien mana yang paling berisiko mengalami 
perkembangan penyakit, yang memungkinkan pasien ini diidentifikasi untuk pemantauan lebih dekat atau intervensi teraupeutik (Obirikorang, 2009).

Dampak yang nyata dari anemia adalah kelelahan. Kelelahan pada infeksi HIV berkaitan dengan gangguan fungsional fisik, distres psikologi dan penurunan kulitas hidup. Meskipun penyebab kelelahan pada anemia bersifat multifaktorial, namun diduga anemia merupakan penyebab paling berpengaruh pada kelelahan. Kelelahan yang terjadi terlihat pada gangguan aktivitas sehar-hari, gangguan kerja, gangguan tidur (Volberding,2004).

Tujuan utama dari tatalaksana anemia pada infeksi HIV adalah mempertahankan hemoglobin normal dan peningkatan hemoglobin. Strategi selanjutnya adalah pemberian nutrisi adekuat dan perencanaan skrining yang lebih sering. Terapi farmakalogi yang dapat diinisiasi segera adalah HAART dan epoetin alfa (recombinant human erythropoietin). Transfusi darah diberikan pada anemia berat (Volberding, 2004)

Penelitian yang sama dilakukan di Bali tahun 2017 oleh Dwiadnyana mendapatkan hasil Menggunakan korelasi spearman, tingkat signifikan korelasi linear positif ditemukan antaratingkat $\mathrm{Hb}$ dan tingkat kadar CD4 $(r=0,698 ; p<0,001)$. menemukan korelasi positif yang kuatantara tingkat $\mathrm{Hb}$ dan tingkat kadar CD4 pada pra antiretroviralpengobatan pasien yang terinfeksi HIV. Penelitian lain yang dilakukan oleh Marin,dkk didapatkan hasil antara kadar CD4 dan hemoglobin $(r=0,595, P<0,001)$ dan korelasi yang cukup kuat. Perbedaan signifikan juga didapatkan pada penelitian observasional oleh Obirikorang konsentrasi hemoglobin darah rata-rata pada mereka dengan jumlah CD4 $<200 \mathrm{~mm}^{-3}, 200-499$ $\mathrm{mm}^{-3}$ dan $\geq 500 \mathrm{~mm}^{-3}(8,83 \pm 0,22 \mathrm{~g}$ / dl, 10,03 $\pm 0,31 \mathrm{~g} / \mathrm{dl}$ dan 11,3 \pm $0,44 \mathrm{~g} \mathrm{/} \mathrm{dl} \mathrm{masing-masing)} \mathrm{secara}$ signifikan lebih rendah bila dibandingkan dengan kelompok kontrol $(14,29 \pm 0,77 \mathrm{~g} / \mathrm{dl})(p$ $<0,0001)$, dan adanya korelasi yang signifikan dan positif antara tingkat hemoglobin darah dan jumlah CD4 mereka $\left(r^{2}=0,1755 ; p<0,0001\right)$.

\section{KESIMPULAN}

1. Rerata kadar T CD4 sebelum terapi ARV pada penderita HIV/AIDS di RSUD DR. H. Abdul Moeloek Provinsi Lampung Tahun 2017 yaitu $151,36 \mathrm{sel} / \mathrm{mm}^{3}$ dengan nilai tengah $89 \mathrm{sel} / \mathrm{mm}^{3}$, nilai minimum $0 \mathrm{sel} / \mathrm{mm}^{3}$ dan nilai maksimum $608 \mathrm{sel} / \mathrm{mm}^{3}$.

2. Rerata kadar Hemoglobin sebelum terapi ARV pada penderita HIV/AIDS di RSUD DR. H. Abdul Moeloek Provinsi Lampung Tahun 2017 yaitu 12,421 gr/dl dengan nilai tengah $12,7 \mathrm{gr} / \mathrm{dl}$, nilai minumum 6,4 gr/dl, dan nilai maksimum 18,5 gr/dl.

3. Terdapat korelasi antara kadar CD4 dengan kadar Hemoglobin ( $p$ $0,00, r=0,458$ )dengan kekuatan korelasi sedang dengan arah korelasi positif

\section{DAFTAR PUSTAKA}

Baratawidjaja, K. G., \& Rengganis, I. (2014). Imunologi dasar edisi ke-10. Jakarta:

Fakultas Kedokteran Universitas Indonesia.

Budimulja, U. (2010). IImu Penyakit Kulit dan Kelamin Edisi Kelima. Jakarta: Fakultas Kedokteran Universitas Indonesia, 345-6.

Cummins, N. W., \& Badley, A. D. (2010). Mechanisms of HIVassociated lymphocyte apoptosis: 2010. Cell death \& disease. 1(11), e99.

Dahlan, M. S. (2015). Statistik untuk kedokteran dan kesehatan. Jakarta: Salemba.

Daili, S. F., Makes, W. I., \& Zubier, F. (2009). Infeksi menular seksual. Cetakan Pertama. Jakarta: Fakultas Kedokteran Universitas Indonesia. Halaman, 363-365. 
Dolin, R., Masur, H., \& Saag, M. S. (2009). AIDS Therapy E-Book. Elsevier Health Sciences.

Dinas Kesehatan Provinsi Lampung. (2015). Profil Kesehatan Provinsi Lampung Tahun 2015. Bandar Lampung. Dari: http://www.depkes.go.id/resou rces/download/profil/PROFIL K ES PROVINSI 2015/08 Lampu ng 2015.pdf

Ditjen PP dan PL Kemenkes RI. (2016). Situasi Penyakit HIV AIDS di Indonesia. Jakarta. Dari:http://www.pusdatin.kem kes.go.id/resources/download/ pusdatin/infodatin/InfodatinSituasi-Penyakit-HIV-AIDS-diIndonesia.pdf

Ditjen PP \& PL. (2011). Pedoman Nasional Tata Laksana Klinis Infeksi HIV dan

Antiretroviral.Jakarta:Depkes RI

Sudoyo AW,et al. Buku Ajar IImu Penyakit Dalam jilid III. Edisi V. Jakarta: Interna Publishing, 2861-70.

Duarsa, N W. (2011). Infeksi menular seksual. Edisi 4. Jakarta: FKUI. Jakarta: Interna Publishing.

Dwiadnyana, S. B. K., Suega, K., \& Merati, K. T. P. (2018). Korelasi antara kadar hemoglobin dengan jumlah limfosit t CD4 pada penderita terinfeksi human immunodeficiency virus (HIV) pra terapi antiretroviral.MEDICINA,49(1), 5-8. DOI: 10.15562/medi.v49i1.251

De Santis, G. C., Brunetta, D. M., Vilar, F. C., Brandao, R. A., de Albernaz Muniz, R. Z., de Lima, G. M. N., \& Machado, A. A. (2011). Hematological abnormalities in HIV-infected patients. International Journal of Infectious Diseases, 15(12), e808-e811.

Dai, G., Xiao, J., Gao, G., Chong, X., Wang, F., Liang, H., ... \& Wang, D. (2016). Anemia in combined antiretroviral

treatment-naive HIV-infected

patients in China: $A$ retrospective study of prevalence, risk factors, and mortality. Bioscience trends, 10(6), 445-453.

DL, A. S., \& Dwi Lestari, D. W. (2015). Faktor-faktor risiko penularan HIV/AIDS pada lakilaki dengan orientasi seks heteroseksual dan homoseksual di Purwokerto. MANDALA of Health, 4(2), 113-123.

Dewi, Y. I. (2015). Identifikasi karakteristik orang risiko tinggi HIV dan AIDS tentang program pelayanan voluntary counseling and testing (VCT). Jurnal Online Mahasiswa (JOM) Bidang IImu Keperawatan, 2(1), 853-862.

Fransiska, Y. Y., \& Kurniawaty, E. (2015). Anemia pada Infeksi HIV. Jurnal Majority, 4(9), 123-128.

Guyton, A. C. (2014). Sel Darah, Imunitas dan Pembekuan Darah. Dalam: Buku Ajar Fisiologi Kedokteran. Penerbit Buku Kedokteran EGC Jakarta.

Hasanah, R. A., \& Rahayu, B. (2017). Karakteristik Pasien Penyakit HIV/AIDS di Puskesmas Gedongtengen Yogyakarta Tahun 2015. Skripsi. Yogyakarta: Sekolah Tinggi Ilmu Kesehatan Jendral Ahmad Yani.

Kambu, Y., Waluyo, A., \& Kuntarti, K. (2016). Umur orang dengan HIV AIDS (ODHA) berhubungan dengan tindakan pencegahan penularan HIV. Jurnal Keperawatan Indonesia, 19(3), 200-207.

Kementerian Kesehatan, R. I. (2017). Data dan Informasi: Profil Kesehatan Indonesia. Jakarta: Kemenkes RI. Dari: http://www.pusdatin.kemkes.g o.id/resources/download/pusda tin/profil-kesehatanindonesia/Data-dan- 
Informasi Profil-Kesehatan-

Indonesia-2017.pdf

Kementerian Kesehatan Republik Indonesia Direktorat Jendral Pencegahan dan Pengendalian Penyakit. 2017. Laporan HIV AIDS TW 1 2017.Jakarta. Dari: http://siha.depkes.go.id/portal /files upload/Laporan HIV AI DS TW 12017 rev.pdf

Kementerian Kesehatan, R. I. (2011). Pedoman nasional tatalaksana klinis infeksi HIV dan terapi antiretroviral pada orang dewasa. Jakarta: Kementerian Kesehatan Republik Indonesia Direktorat Jenderal Pengendalian Penyakit dan Penyehatan Lingkungan, 1-60.

Lubis, Z. D. (2012). Gambaran Karakteristik Individu dan Faktor Resiko Terhadap Terjadinya Infeksi Oportunistik pada Penderita HIV/AIDS di Rumah Sakit Penyakit Infeksi Sulianti Saroso. Fakultas Kesehatan Masyarakat UI.

Luthfiana, Y. (2012). Hubungan Pengetahuan dan Sikap Terhadap Perilaku Beresiko HIV/AIDS pada Pekerja Bangunan di Proyek World Class University Tahun 2012. Jakarta: Universitas Indonesia.

Merati, T., \& Djauzis, J. (2009). Respon Imun Infeksi HIV dalam Buku Ajar IImu Penyakit Dalam.Jakarta:Interna Publishing

Mishra, S., Dwivedi, S. P., Dwivedi, N., \& Singh, R. B. (2009). Immune response and possible causes of CD4+ T-cell depletion in human immunodeficiency virus (HIV)1 infection. Open Nutra $J, 2$, 46-51.

Murray, R. K., Granner, D. K., Mayes, P. A., \& Rodwell, V. W. (2014). Biokimia harper. Edisi, 25, 280-281.

Nasronudin. (2014). Buku Ajar IImu Penyakit Dalam. Edisi VI. Jakarta: Interna Publishing
Notoatmojo, S. (2014). Metodologi Penelitian Kesehatan, Edisi kedua. Rineka Cipta, Jakarta.

Obirikorang, C., \& Yeboah, F. A. (2009). Blood haemoglobin measurement as a predictive indicator for the progression of HIV/AIDS in resource-limited setting. Journal of biomedical science, 16(1), 102.

Pohan, H. T. (2009). Infeksi dibalik ancaman HIV. Penerbit Farmacia. Jakarta.

Pramitasari, R. and Aryani, L., (2018). PREVALENSI KASUS AIDS PADA PEKERJA DI KOTA SEMARANG-ANALSISI DATA SEKUNDER. JURNAL

KESEHATAN MASYARAKAT
INDONESIA, 13(1).

Price, S. A., \& Wilson, L. M. 2013. Patofisiologi konsep klinis proses-proses penyakit. Jakarta: Egc, 437450.

RI, K., 2015. Peraturan Menteri Kesehatan Republik Indonesia Nomor 87 Tahun 2014 tentang Pedoman Pengobatan Antiretroviral. Jakarta:

Kementerian Kesehatan Republik Indonesia.

Robbins, S. L., Cotran, R., \& Kumar, V. (2009). Dasar Patologis Penyakit. Edisi ke-7. Jakarta: EGC.

Roselinda, R., Wibowo, H.A. and Setiawaty, V.(2015). Karakteristik Pekerjaan Pada Kasus Human Immunodeficiency Virus-1 Dan Subtipenya Di Tujuh Provinsi Di Indonesia Pada Tahun 2011. Indonesian Journal of Biotechnology Medicine, 4(2), pp.71-76.

Sastroasmoro, S., \& Ismael, S. (2011). Dasar-dasar metodologi penelitian klinis. Jakarta: Sagung Seto, 372.

Saktina, P. U., \& Satriyasa, B. K. (2017). Karakteristik Penderita AIDS dan Infeksi Oportunistik di Rumah Sakit Umum Pusat 
Sanglah Denpasar Periode Juli 2013 sampai Juni 2014. EJurnal Medika, 6(3), 1-6.

Sharma, S., Dhungana, G. P., Pokhrel, B. M., \& Rijal, B. P. (2010). Opportunistic infections in relation to CD4 level among HIV seropositive patients from central Nepal. Nepal Med Coll J, 12(1), 1-4.

Shen, Y., Wang, Z., Lu, H., Wang, J., Chen, J., Liu, L., \& Zheng, Y. (2013). Prevalence of anemia among adults with newly diagnosed HIV/AIDS in China. Plos One, 8(9), e73807.

Sugiyono. (2016). Metode Penelitian Kuantitatif, Kualitatif dan R\&D. Bandung: PT Alfabet.

Sumantri, R., Wicaksana, R., \& Ariantana, A. R. (2009). Prevalensi dan faktor risiko anemia pada HIVAIDS. Majalah Kedokteran Bandung, 41(4).

Sysmex-Europe. (2015). Fluorescence Flow Cytometry. Dari: http://www.sysmexeurope.co m/academy/knowledgecentre/ measurementtechnologies/fluo rescence-flow-cytometry.html. Diunduh pada 15 Januari 2019.

Sysmex UK. (2016). Haematology Measurement Technologies. Diakses pada tanggal 15 Januari 2019, dari: http://www.sysmex.co.uk/educ ation/knowledgecentre/measur ementtechnologies/haematolog y-measurementtechnologies. html.

UNAIDS.(2017). Fact-sheet world aids day 2017.

Dari: http://www.unaids.org/sit es/default/files/media asset/U NAIDS FactSheet en.pdf

Volberding, P. (2002). The impact of anemia on quality of life in human immunodeficiency virus-infected patients. The Journal of infectious diseases, 185(Supplement_2), $\mathrm{S} 110-\mathrm{S} 114$

Volberding, P. A., Levine, A. M., Dieterich, D., Mildvan, D., Mitsuyasu, R., Saag, M., \& Anemia in HIV Working Group. (2004). Anemia in HIV infection: clinical impact and evidence-based management strategies. Clinical infectious diseases, 38(10), 1454-1463.

WHO dan UNAIDS.(2004). Technical Information in : CD4+ T-Cell Enumeration Technologies. Dari:http://www.who.int/diagn ostics laboratory/publications/ en/cd4 is draft.pdf

WHO. (2011). Hemoglobin concentrations for the diagnosis of anemia and assessment of severity. Vitamin and Mineral Nutrition Information System. Geneva: World Health Organization; 2011.

Wipasa, J., Wongkulab, P., Chawansuntati, K., Chaiwarit, R., \& Supparatpinyo, K. (2014). Cellular immune responses in HIV-negative immunodeficiency with antiinterferon- $y$ antibodies and opportunistic intracellular microorganisms. PloS one, 9(10), e110276.

Woldeamanuel, G. G., \& Wondimu, D. $\mathrm{H}$. (2018). Prevalence of anemia before and after initiation of antiretroviral therapy among HIV infected patients at black lion specialized hospital, Addis Ababa, Ethiopia: a cross sectional study. BMC hematology, 18(1), 7. 